\title{
RESEARCH FORMULATION PROBLEMS FACED BY STUDENTS IN WRITING RESEARCH PROPOSAL
}

\author{
(A Case Study at the Fifth Semester of English Department \\ in 2019/2020 Academic Year )
}

\author{
Beniario \\ FKIP Universitas Muhammadiyah Sumatera Barat \\ beni.ario88@gmail.com
}

\begin{abstract}
Some studies had indicated that writing the research proposal had dissimilarly perspective, the view being a framework to design a research proposal, how to write the research proposal in various subject areas through analysing the students' projects such as Susetyo and Noermansyah, (2020), Lestari, Monica (2020), and Sahib, Rahmawansyah and Murshid (2020). However, the studies focused on what the students' difficulties, and what kinds of mistakes made by the students in writing research proposal, so the trend studies had particularly concerned with the weaknesses in writing research, but needs some studies more in exploring research paradigm to develop research theories. This article provides with how the research formulation made by the students in introduction, research design and research methodology applied in writing research proposal in 2020/2021 academic year? The population of the data was random sampling; all the students took the seminar on language teaching. The instrument of this research were students' proposal writing, the data were analysed by checking the students' writing, identifying, describing and concluding the result of students perspective in writing. The result showed that the students made the research formulation were fully unable neither introductory, review of related literature or research methodology. This article was strongly recommended to students and lecturer to learn the course in a team in order to be more various and attractive.
\end{abstract}

Key words: formulation, problems, research proposal

\begin{abstract}
ABSTRAK
Beberapa penelitian menunjukkan bahwa penulisan proposal penelitian memiliki perspektif yang berbeda, yaitu pandangan menjadi kerangka untuk merancang proposal penelitian, bagaimana menulis proposal penelitian di berbagai bidang studi melalui analisis proyek-proyek mahasiswa seperti Susetyo dan Noermansyah, (2020), Lestari, Monica (2020), dan Sahib, Rahmawansyah dan Murshid (2020). Namun demikian, kajian difokuskan pada apa kesulitan mahasiswa, dan kesalahan apa yang dilakukan mahasiswa dalam menulis proposal penelitian, sehingga kajian tren lebih menitikberatkan pada kelemahan penulisan penelitian, namun perlu adanya kajian lebih dalam menggali paradigma penelitian. mengembangkan teori penelitian. Artikel ini menjelaskan bagaimana rumusan penelitian yang dibuat oleh mahasiswa dalam pendahuluan, desain penelitian dan metodologi penelitian yang diterapkan dalam penulisan proposal penelitian tahun ajaran 2020/2021 ?. Populasi datanya adalah random sampling; semua siswa mengikuti seminar tentang pengajaran bahasa. Instrumen penelitian berupa penulisan proposal siswa, analisis data dilakukan dengan mengecek tulisan siswa, mengidentifikasi,
\end{abstract}


mendeskripsikan dan menyimpulkan hasil perspektif siswa dalam tulisan. Hasil penelitian menunjukkan bahwa mahasiswa yang membuat rumusan penelitian tidak mampu sepenuhnya baik pengantar, telaah pustaka terkait maupun metodologi penelitian. Artikel ini sangat menganjurkan kepada mahasiswa dan dosen untuk mempelajari mata kuliah secara tim agar lebih variatif dan menarik.

Kata kunci: rumusan, masalah, proposal penelitian

\section{INTRODUCTION}

It is a greatly consideration of the writing research proposal as pre-final project to fulfill one of the scholar requirements in every high institution, the requirement being the interest studies to be developed as the students highest level-thinking competence, so the research formulation as a highlighted view in the trend studies. Even though, the issue had overviewed in conference, workshop and seminar in other countries including Indonesia yet it needs some exploration more specific in every field studies. In Malaysia, research proposal also being compulsory subject for the postgraduate student which is called by the research skills (Krish, Salehuddin and Razak, 2017).

Some issues had taken account of relating to writing research proposal namely; Susetyo and Noermansyah, (2020), Lestari, Monica (2020), and Sahib, Rahmawansyah and Murshid (2020). Those views discussed how the students' ability and difficulties in writing research proposal, but a little attentions of research focusing on how the research formulation made by the students in writing the research proposal, so this article specifically promoted how the students illustrate the sources of problems, how they choose the relevant theories, and how they state the research methodology in the research proposal.

Dealing with the concerning, a number of theories supporting how the students choose the source of problems are experiences, deduction from theories and related literature (Ary Donald et. al (2010: 44). Someone experience can be a source of problem to carry out the research because he/she understood the real situation in the field for many years, so he/she known how to put the correction position. Then, theories can be a source of problems in the research, the interrelated statement or mismatching views can be conducted a research by comparing the theories, those theories may be weaknesses or strengths in applying in the field. Last, related literature can be a source of problem to conduct a research, related literature can be a source of problem to guide, support, and complete a research. This composition in designing the research formulation should be described in introduction; how the introduction of the research explains the research gap in elaborating the current issue become an interesting trend to be explored; what the formulation should be stated to support and to critic the previous research in the introduction. (Mursyid and Sahib: 2020). The viewpoint of the introduction of the research being dissimilar of this paper is a consideration of the research may be contributed to the source of the problems and either interests neither theme nor research purposes should be clearly described, so research paradigm is not to find out the problem but to draw up the subject interest.

Relating to the theories above, reviewing related literature as an instrument to define the object of the research, The role of related literature can be the frontiers of the field, to place a question in perspective, to clarify the research question and 
define the concepts of the study, to avoid the unintentional replication of the previous studies, and to state the position of the research. Ary Donald, et al (2010: 64) Choosing the theories in writing the research proposal is a clue to stress the research would be carried out, the literature would measure the perspective point in analyzing the appropriate research with research purposes.

Finally, research method is a vehicle to undergo the research, what type of the research, how to apply, what procedure, how to measure and how to display the data of the research also stated clearly in doing a research. Communicating the research data can be serious attention for every field of studies, inasmuch as carrying research method in methodology is a compulsory in understanding the research.

\section{METHODOLOGY}

The research design was as qualitative, described the phenomena involve the people and case of interest (Creswell, 2009) the research process started from collecting, analysis and interpreting. The data source were gathered from a research proposal of the students in 2019/2020 academic year, the two research proposal were randomly selected and analysed using thematic analysis technique. The proposal represented the level of the students achievement based on the GPA. And the two proposals were analysed in the line with element of introductory, review of related theories and research methodology. Here the source of data;

\begin{tabular}{|l|l|l|}
\hline Participant & Gender & Proposal title \\
\hline NH & Female & $\begin{array}{l}\text { The effectiveness of using card fishing } \\
\text { game to improve students' } \\
\text { understanding of simple present tense in } \\
\text { the second grade of MTsN I Padang } \\
\text { Panjang }\end{array}$ \\
\hline JS & Male & $\begin{array}{l}\text { The effect of picture word model } \\
\text { strategy toward students writing skill in } \\
\text { descriptive text }\end{array}$ \\
\hline
\end{tabular}

(Students research proposal on even semester 2019/2020 in academic year)

\section{FINDING AND DISCUSSING}

This finding and discussing of the article explained how the student made the research formulation in writing research proposal of the introduction, literature and research methodology. The data analysis can be seen from displaying the research formulation on introduction made by the students.

\section{Datum 1}

There are many types of card games that can support learning activities about the simple present tense. In this case, the researcher will focus on using the card fishing game to improve students' understanding of the simple present tense. (Page $2,3^{\text {rd }}$ paragraph)

That statement in the proposal was learning activities about the simple present, here the writer thinks simple present is something to be learned but it is a language use in communicative language teaching (CLT) perspective, how to design simple present as communication by using game or card fishing game, so formulation of the problem as source of experience, review theories, and related literature cannot be categorized as a research formulation in introduction. 


\section{Datum 2}

Some problem in writing process, first, the student get difficulties in developing ideas and lack of vocabulary, second, the students are not able to produce their own idea into a write form because they are lack of grammar, third, they do not know how to write a written language especially descriptive text, forth, the students are error in grammar, spelling, capitalization, punctuation, and mechanic. (page $4,1^{\text {st }}$ paragraph)

Truly, this statement tried to classify the problem in experience perspective as a source of problem, for instance; first the student get difficulties... second the students are not able to... but did not support with the proof or data may be test, interview and observation, so formulation of the problem as source of problem such as experience, review theories, and related literature cannot be categorized as a research formulation in introduction (Ary Donald; 2010).

Furthermore, the data of review of related to literature of students research proposal can be seen as below:

\section{Datum 3}

..the writer chose card fishing game for cooperative games, where the game is played in collaboration in the form of small group..... (page $8,1^{\text {st }}$ paragraph)

The datum 3 stated that how to formulate the theories became the instrument to carry out the research, the theories function to limit the statement that would be observed, the writer chose card fishing game for cooperative games, so how the simple present operate in using game, the datum 3 explained the definition of that game but it did not mean as procedures or step in using game. This statement can be classified as formulation in writing the theories needed in review of related literature.

\section{Datum 4}

The method ..it can be used toward students' writing skill with consider for the component of the writing itself especially in vocabulary, grammar, gathering idea, mechanic, and language use too. (Page $16,2^{\text {nd }}$ paragraph)

The datum 4 as formulation in applying the theories also stated as definition of writing component such as it can be used toward students' writing skill with consider for the component of the writing but in review theories needed how to apply the theories in teaching writing did not explain again the component of the writing.

The data of research methodology of students' research proposal can be seen as below:

\section{Datum 5}

.this study uses an experimental method to test whether the card fishing game is effective as alternative way of teaching simple present tense.. (page 19, $2^{\text {nd }}$ paragraph)

The data 5 and 6 as data for classifying the research methodology in conducting a research, here the data; this study uses an experimental method to test whether the card fishing game is effective as alternative way of teaching simple present tense. Experimental research consisted of free, quasi, pure experiment of kinds of research experiment. This research function to undergo and to prove the hypothesis was accepted or not, so the formulation in making the research method cannot be also classified as a good formulation.

\section{Datum 6}


..this research was experimental research which is conducted by posttest only control design. For the posttest, both of group will get the same test..(page 23, $3^{\text {rd }}$ paragraph)

The datum 6 also stated directly and did not state what kind of research experimental such as this research was experimental research which is conducted by posttest only control design. For the posttest, so this statement is unclearly enough to undergo a research design and cannot be identified as a research formulation in research methodology, it should be stated the research design in such free experiment and pure experiment in conducting research.

\section{CONCLUSION}

To sum up the article how the students write the research formulation in introductory, related theories and research methodology were uncategorized. They were unable to identify what a source of problem in writing the introduction; they just wrote whatever they remembered so that was no scientific writing paper, in meaning the theories were hardly understood well, the theories put together and stand itself and did not apply as statement limitation on the object of the research to focus what to do the theories, and research methodology cannot be operated well for instance what research design. This research was strongly recommended for the all participants whether students and even lecturer in teaching the research methodology they should take account of how to design research formulation in writing introduction, theories and research method by reading the new materials, course book, handbook a lot and support with discussion or focus group discussion, for stakeholder should be in team teaching for research methodology course.

\section{REFERENCES}

Ary. Donal. 2010. Introduction to Research in Education $8^{\text {th }}$ Edition. United states: Wadsworth Cengage Learning.

Creswell, John .W. 2009. Research Design: Pendekatan Kualitatif, Kuantitatif, dan Mixed. Yogyakarta: Pustaka Pelajar

Lestri. Dwi, monica. 2020. An analysis of students' difficulties in writing Undergraduate thesis at english education program of Muhammadiyah University of Bengkulu. Journal of English Education and Applied Linguistics. https://fkip.ummetro.ac.id/journal/index.php/english.

Sahib. Rahmansyah and Murshid 2020. An Analysis of Research Backgrounds of EFL Students Research Proposal. Journal of English language Studies. Vol. 5 no 2. 2020. 199-209.

Susetyo and Noermansyah. 2020. Kemampuan dan kesulitan mahasiswa program studi Pendidikan bahasa indonesia universitas bengkulu Dalam menulis proposal penelitian skripsi. STKIP PGRI LubukLinggau. LP4MK. ISSN. 2620-3316

Krish, Razak. Norizan. A. 2017. Engaging Postgraduate Students in Preparing Research Proposals. Akademika. April 2017:243-252. http://doi.org/10.17576/akad-2017-8701-18 